\title{
PURIFICATION OF WATER FROM URANYL-IONS BY NEW SORBENT OF CARBOXYLATE TYPE
}

\author{
${ }^{a}$ A.M. Maharramov, ${ }^{a}$ M.R. Bairamov, ${ }^{\text {a }}$ G.M. Askarova, ${ }^{b}$ J.A. Naghiyev,

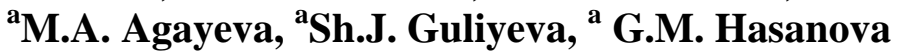 \\ ${ }^{a}$ Baku State University \\ Z.Xalilov str., 23, Baku AZ 1148, Azerbaijan Republic; e-mail: gull.askar@mail.ru \\ ${ }^{b}$ National Nuclear Research Centre of Azerbaijan \\ Inshaatchilar ave. 4, Baku, AZ 1073 \\ Recieved 02.05.2018
}

\begin{abstract}
The hydrolyzed ternary copolymer of styrene, maleic anhydride and 1,3-bis(2-propenylphenoxy)propane was studied as sorbent for extraction of uranyl-ions out of aqueous systems. The influence of $\mathrm{pH}$ medium, concentration of uranyl-ions, quantity of sorbent, duration of sorption and other factors on main indices of the sorption process was analyzed. The analysis of isotherms of sorption of uranyl-ions was performed through the use of Langmuir and Freundlich's equations. The possibility of using the copolymer both in concentrated and diluted solutions established.
\end{abstract}

Keywords: cross-linked copolymers, isotherms of sorption, regeneration, sorption, uranyl-ions

\section{INTRODUCTION}

As is known, the development of effective methods of purification of aqueous systems from ions of heavy metals, radionuclides and other harmful substances is one of the priority directions of the chemical science [1-3].

In spite of the fact that recently there have been proposed the various sorption methods of purification from above-mentioned toxicants, an emphasis is laid on making new materials with high functional properties, especially as regards sorbents of complexforming type which can be easily regenerated and reused [4].

Radionuclides in aqueous solutions are usually in the hydrolyzed form which largely accounts for their behavior in the sorption processes, ion exchange, extraction, etc. In the compounds, the uranium shows a valence state (from 2 to 6). However, in the aqueous medium, $\mathrm{U}(\mathrm{VI})$ is the most stable in the form of $\mathrm{UO}_{2}{ }^{2+}$-ions to create mononuclear and polynuclear hydroxocomplexes [5].

The works [6] revealed that for effective binding of $\mathrm{UO}_{2}{ }^{2+}$-ions from aqueous solutions it'd be appropriate to use the synthetic sorbenthydrolized cross-linked copolymer of styrene, maleic anhydride and 1,3-bis-(2isopropenylphenoxy)-butane developed by us.

The paper deals with the synthesis of cross-linked copolymer of styrene, maleic anhydride and 1,3-bis-(2-propenylphenoxy) propane to examine them as sorbent for purification of aqueous solutions from uranyl salts.

\section{EXPERIMENTAL PART}

The radical ternary copolymerization reaction of styrene, maleic anhydride and 1,3bis-(2-propenylphenoxy)-propane (at their ratio 1:2:0,2 mol) was analyzed with a view of preparing a new sorbent with cross-linked structure. The last one was synthesized
(Williamson reaction) through the interaction of 2-propenylphenol with 1,3-dibromopropane (in the presence of alcohol solution of $\mathrm{KOH}$ and promoter KY). The copolymerization was carried out in a medium of solvating solvent (200\% of dioxane). As a template there was 
used a linear copolymer of styrene with maleic anhydride (4\% per taken reagents).

The copolymerization process was carried out in the presence of initiator dinitrile of azoizobutyric acid (1\% per mixture of monomers), at temperature $80^{\circ} \mathrm{C}$ during 10 hours.

In the end of template synthesis aimed at separating a pore agent (linear copolymer of styrene with maleic anhydride) from cross- linked copolymer, it was extracted (at the Soxhlet apparatus) first by acetone, then by toluene. The cross-linked copolymers were dried up at temperature $40-50^{\circ} \mathrm{C}$ for 2 hours in the vacuum box with yield $~ 95 \%$ (thereof).

The last ones were further treated by hot water for 2 hours with the aim of opening anhydride rings and preparing a sorbent with carboxyl groups in their structure:<smiles>CC(C)CC(C)C(C)C(=O)O</smiles>

To reveal the possibility of use of last one as sorbent for extraction of uranium compounds, comprehensive laboratory explorations in static conditions were carried on model systems consisting of solutions with sertain concentration of uranyl sulfate in distilled water. To regulate $\mathrm{pH}$ medium, ammonia acetate solutions through mixing corresponding volumes of $0,1 \mathrm{M} \mathrm{CH} \mathrm{CH}_{3} \mathrm{COOH}$ with $0,1 \mathrm{M} \mathrm{NH} \mathrm{N}_{3}$ were used. Also, fixanal $\mathrm{HCl}$ was used.

An estimation of sorption properties was carried out by determination of isotope ${ }^{238} \mathrm{U}$ activity in aqueous phase (before and after sorption) by $\gamma$-spectrometer HPGe with germanium detector (made in USA).

The influence of $\mathrm{UO}_{2}{ }^{2+}$-ions concentration of $\mathrm{pH}$, quantity of sorbent, endurance time and other parameters on degree of their sorption (R, \%) and sorption capacity of sorbent (SCS, mg/g) was analyzed.

Note that respective experiments were carried out as follows: some quantities of copolymer and aqueous solution of uranylsulfate of a given concentration are loaded into a teflon cup with capacity of $100 \mathrm{ml}$. Then, 10 $\mathrm{ml}$ of $0.1 \mathrm{M}$ buffer solution was added to the mixture and its volume brought to $50 \mathrm{ml}$ (a dilution with distilled water). The system is kept at a room temperature for some time, after which in the aqueous solution it is determined a content of $\mathrm{UO}_{2}{ }^{2+}$ ions. Based on the obtained data R and SCS are calculated. The equilibrium of sorption of uranyl ions on the synthesized sorbent was examined at 293 $\mathrm{K}$ under static conditions. The equilibrium concentration of the uranyl ion have also been determined by $\gamma$-spectrometer.

\section{RESULTS AND DISCUSSION}

Table 1 shows the results of research into the influence of $\mathrm{pH}$ medium on $\mathrm{R}$ and SCS (duration of endurance - 24 hours, quantity of sorbent $-20 \mathrm{mg}$ ). The concentration of $\mathrm{UO}_{2}{ }^{2+}$-ions in the initial solutions in these series made up $236 \mathrm{mg} / \mathrm{l}$ and the activity - ${ }^{235} \mathrm{U} \mathrm{Bq} / \mathrm{l}$. 
Table 1. Influence of $\mathrm{pH}$ of aqueous solution on $\mathrm{R}$ and SCS values

\begin{tabular}{|c|c|c|c|c|}
\hline pH of solution & $\begin{array}{c}\text { Activity of isotope } \\
{ }^{235} \mathrm{U} \text { after sorption, } \\
\mathrm{Bq} / \mathrm{l}\end{array}$ & $\begin{array}{c}\text { Concentration of } \mathrm{UO}_{2}{ }^{2+}- \\
\text { ions in solution after } \\
\text { sorption, } \mathrm{mg} / \mathrm{l}\end{array}$ & $\mathrm{R}, \%$ & $\mathrm{SCS}, \mathrm{mg} / \mathrm{g}$ \\
\hline 1,0 & 120 & 236,0 & 0 & 0 \\
2,0 & 109 & 214,4 & 9,2 & 54,1 \\
3,0 & 104 & 204,5 & 13,3 & 79,7 \\
3,85 & 89 & 175,0 & 25,8 & 152,4 \\
4,8 & 65 & 127,8 & 45,8 & 270,4 \\
5,7 & 31 & 61,4 & 74,0 & 236,6 \\
6,2 & 30 & 57,2 & 75,8 & 436,9 \\
8,0 & 32 & 62,9 & 73,3 & 432,7 \\
9,0 & 92 & 181,5 & 23,1 & 136,2 \\
10 & 120 & 236,0 & 0 & 0 \\
11 & 115 & 226,2 & 4,2 & 24,6 \\
12 & 120 & 236,0 & 0 & 0 \\
13 & 117 & 230,1 & 2,5 & 14,8 \\
14 & 118 & 232,1 & 1,7 & 9,8 \\
\hline
\end{tabular}

In an effort to find the possibility of using the copolymer for $\mathrm{UO}_{2}{ }^{2+}$-ions concentration from diluted solutions, we have carried out further experiments where initial concentrations alternated in a wider range (2.4 $\mathrm{mg} / \mathrm{l}$ to $778.8 \mathrm{mg} / \mathrm{l})$. These studies were also carried out under static conditions at a room temperature and an optimum value of $\mathrm{pH} \sim 6$. Duration of sorption was 24 hours. The obtained results are presented in Table 2.

Table 2. Influence of $\mathrm{UO}_{2}{ }^{2+}$-ions in the solution on $\mathrm{R}$ and SCS

\begin{tabular}{|c|c|c|c|c|c|}
\hline \multicolumn{2}{|c|}{$\begin{array}{c}\text { Activity of isotope } \\
\mathrm{Bq} / \mathrm{l}\end{array}$} & \multicolumn{2}{c|}{$\begin{array}{c}\text { Conc. of } \mathrm{UO}_{2}{ }^{2+} \text {-ions in water, } \\
\text { mg/l }\end{array}$} & \multirow{2}{*}{$\mathrm{R}, \%$} & \multirow{2}{*}{ SCS, mg/g } \\
\cline { 1 - 4 } before sorption & after sorption & before sorption & after sorption & & \\
\cline { 1 - 4 } 1,2 & 0.11 & 2.4 & 0.2 & 90.8 & 2.7 \\
2,4 & 0.19 & 4.7 & 0.4 & 92.1 & 5.4 \\
3,6 & 0.44 & 7.1 & 0.9 & 87.8 & 7.8 \\
14,4 & 1.13 & 28.3 & 2.2 & 92.2 & 32.6 \\
28,28 & 2.9 & 56.6 & 5.7 & 89.9 & 63.7 \\
43,2 & 4.2 & 85.0 & 8.3 & 90.3 & 95.9 \\
86,4 & 6.8 & 189.9 & 13.0 & 92.4 & 196.2 \\
120,0 & 12.1 & 236.0 & 23.8 & 90.0 & 265.3 \\
180,0 & 45.5 & 354.0 & 88.7 & 74.9 & 331.6 \\
216,0 & 62.6 & 424.8 & 123.1 & 71.0 & 377.1 \\
252,0 & 79.6 & 495.6 & 156.1 & 68.4 & 423.8 \\
288,0 & 100.1 & 566.4 & 196.9 & 65.2 & 461.9 \\
324,0 & 136.2 & 637.2 & 256.9 & 58.3 & 464.1 \\
360,0 & 166.3 & 708.0 & 327.1 & 53.8 & 476.2 \\
396,0 & 199.5 & 778.8 & 392.4 & 49.6 & 483.1 \\
\hline
\end{tabular}

According to Table 2, the copolymer has solutions. A degree of extraction of $\mathrm{UO}_{2}{ }^{2+}$ high sorption properties in relation to $\mathrm{UO}_{2}{ }^{2+}$ - ions from concentrated solution (with content ions both in concentrated and diluted aqueous $\quad 190 \mathrm{mg} / \mathrm{l} \mathrm{UO}_{2}{ }^{2+}$-ions) is $92.4 \%$ where SCS is 
$196.2 \mathrm{mg} / \mathrm{g}$. Further increase of the ions concentration in the initial solution makes up to $236 \mathrm{mg} / \mathrm{l}$ and R to $90 \%$, and SCS - to 265.3 $\mathrm{mg} / \mathrm{g}$. When used strongly concentrated solutions (content 708.0 and $778.8 \mathrm{mg} / \mathrm{l}$ $\mathrm{UO}_{2}{ }^{2+}$-ions), $\mathrm{R}$ value averages to $\sim 50 \%$.
To calculate the sorption constants, the well-known Freundlich and Langmuir equations were used.

An estimation of the distribution of uranyl-ions on heterogeneous sorption surfaces can be described by empirical Freundlich equation

$$
q_{e}=K_{F}+C_{c}^{n}(1)
$$

where $\mathrm{K}_{\mathrm{F}}-$ Freundlich constant characterizing the adsorption capacity

$\mathrm{n}$ - surface heterogeneity index; $0 \leq \mathrm{n} \leq 1$

In $n \rightarrow 1$ a heterogeneity decreases and in $n=1$, the Freundlich equation passes over to linear isotherm.

Table 3 presents the calculated and $n$ constants were revealed from the parameters of the Freundlich sorption. The $\mathrm{K}_{\mathrm{F}}$ linearized form of the equation

$$
\log q_{e}=\log K_{F}+\frac{1}{n} \log C_{e}
$$

where $\mathrm{C}_{\mathrm{e}}$ - concentration of uranyl ions in the solution after sorption

$\mathrm{q}_{\mathrm{e}}-$ quantity of uranyl ions relating to sorbent, $\mathrm{mg} / \mathrm{g}$

$\mathrm{n}$ - sorbent heterogeneity index

$\mathrm{K}_{\mathrm{F}}$ - sorption capacity constant determined experimentally

Table 3. Parameters of Freundlich sorption

\begin{tabular}{|c|c|c|c|c|c|c|}
\hline $\begin{array}{c}\text { Activity } \\
\begin{array}{c}{ }^{235} \text { before } \\
\text { sorption, } \\
\mathrm{A}_{0}, \mathrm{~Bq} / \mathrm{l}\end{array}\end{array}$ & $\begin{array}{c}\text { Activity } \\
{ }^{235} \mathrm{U} \text { after } \\
\text { sorption, } \\
\mathrm{A}, \mathrm{Bq} / \mathrm{l}\end{array}$ & $\begin{array}{c}\text { Concentration } \\
\text { of uranyl-ions } \\
\text { before sorption, } \\
\mathrm{C}_{0}, \mathrm{mg} / \mathrm{l}\end{array}$ & $\begin{array}{c}\text { Concentration } \\
\text { of uranyl-ions } \\
\text { after sorption, } \\
\mathrm{C}_{\mathrm{e}}, \mathrm{mg} / \mathrm{l}\end{array}$ & $\log \mathrm{C}_{\mathrm{e}}$ & $\begin{array}{c}\mathrm{SCS}, \\
\mathrm{q}_{\mathrm{e}}, \\
\mathrm{mq} / \mathrm{l}\end{array}$ & $\log \mathrm{q}_{\mathrm{e}}$ \\
\hline 1.2 & 0.11 & 2.4 & 0.2 & 0 & 2.7 & 0.081 \\
\hline 2.4 & 0.19 & 4.7 & 0.4 & 0 & 5.4 & 0.069 \\
\hline 3.6 & 0.44 & 7.1 & 0.9 & 0 & 7.8 & 0.111 \\
\hline 14.4 & 1.13 & 28.3 & 2.2 & 0.347 & 32.6 & 0.068 \\
\hline 28.8 & 2.9 & 56.6 & 5.7 & 0.756 & 63.7 & 0.090 \\
\hline 43.2 & 4.2 & 85.0 & 8.3 & 0.917 & 95.9 & 0.086 \\
\hline 86.4 & 6.6 & 169.9 & 13.0 & 1.113 & 196.2 & 0.066 \\
\hline 120.0 & 12.1 & 236.0 & 23.8 & 1.377 & 265.3 & 0.090 \\
\hline 180.0 & 45.1 & 354.0 & 88.7 & 1.948 & 331.6 & 0.267 \\
\hline 216.0 & 62.6 & 424.8 & 123.1 & 2.090 & 377.1 & 0.326 \\
\hline 252.0 & 79.6 & 495.6 & 156.5 & 2.195 & 423.8 & 0.369 \\
\hline 288.0 & 100.1 & 566.4 & 196.9 & 2.294 & 461.9 & 0.426 \\
\hline 324.0 & 135.2 & 637.2 & 265.9 & 2.425 & 464.1 & 0.573 \\
\hline 360.0 & 166.3 & 708.0 & 327.1 & 2.515 & 476.2 & 0.687 \\
\hline 396.0 & 199.5 & 778.8 & 392.4 & 2.594 & 483.1 & 0.812 \\
\hline
\end{tabular}




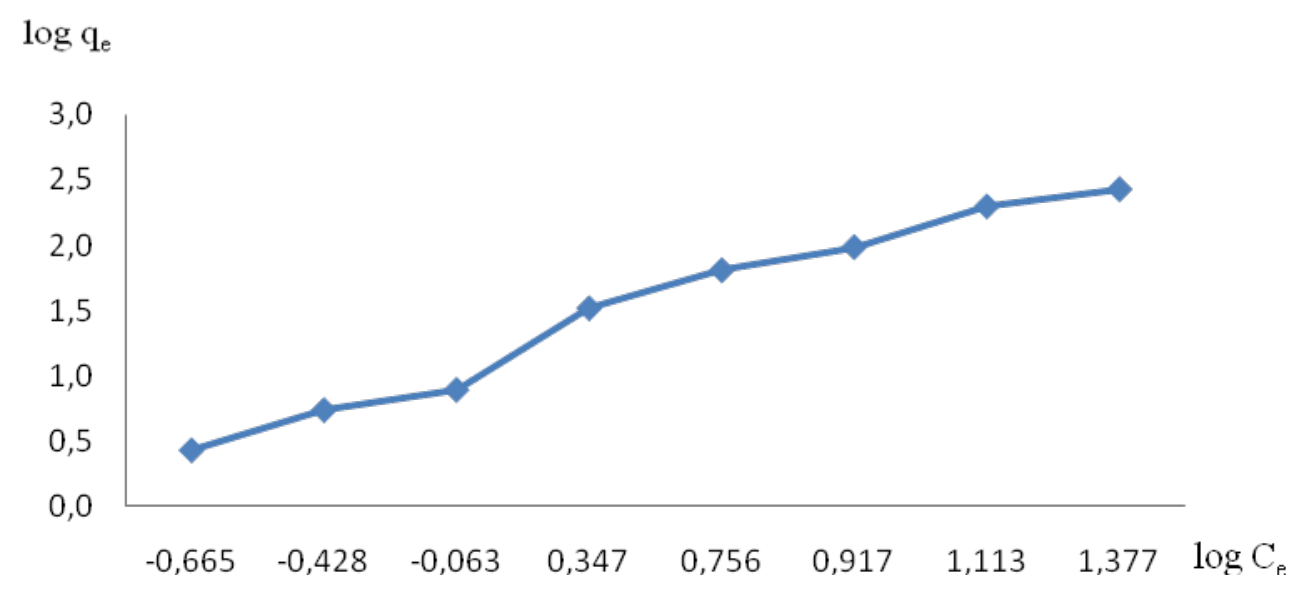

Fig. 1. Freundlich isotherm

To characterize the sorption process of built. The sorption isotherm constants were uranyl-ions, the Langmuir isotherm was also calculated by the following equations:

$$
\frac{C_{e}}{q_{e}}=\frac{1}{K_{L}}+\frac{a_{L}}{K_{L}} C e \quad ; \quad q_{e}=\frac{Q_{\max } a_{L} C_{e}}{1+a_{L} C_{e}}
$$

$\mathrm{C}_{\mathrm{e}}$ - concentration of uranyl-ions in the solution after sorption, $\mathrm{mg} / \mathrm{l}$

$\mathrm{q}_{\mathrm{e}}$ - quantity of connected sorbent of uranium, mg/g

$\mathrm{K}_{\mathrm{L}}-$ sorption constant $\mathrm{l} / \mathrm{g}$

$\mathrm{a}_{\mathrm{L}}$ - constant characterizing the sorption energy l/mg

$\mathrm{Q}_{\max }$ - maximum sorption capacity of the sorbent, $\mathrm{mg} / \mathrm{g}$

The same Table presents the Freundlich isotherm constant.

The Langmuir isotherm is shown in Fig. 2.

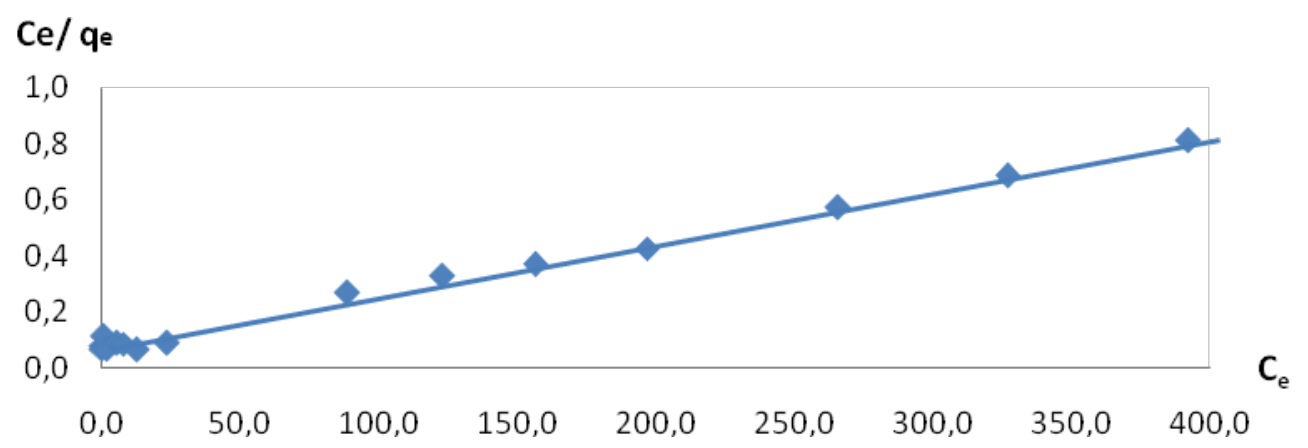

Fig. 2. Langmuir isotherm

An intercept at the intersection of a straight line with ordinate axis corresponds to $1 / \mathrm{KL}$.

According to the formula:

$$
R_{L}=\frac{1}{1+b C_{0}}
$$

Where $b\left(a_{L}\right)$ - Langmuir constant 
$\mathrm{C}_{0}$ - initial concentration of uranyl-ions in the solution, $\mathrm{mg} / \mathrm{l}$; were calculated $\mathrm{R}_{\mathrm{L}}$ of Langmuir isotherm.

It should be noted that if this constant will take the values in the range $0<R_{L}<1$, the sorption process can be considered as profitable, at $\mathrm{R}_{\mathrm{L}}>1$ - unprofitable and in $\mathrm{R}_{\mathrm{L}}=$ 0 - irreversible). The Freundlich and Lanqmuir isotherm constants are shown in Table 4.

Table 4. Freundlich and Lanqmuir isotherm constants

\begin{tabular}{|c|c|c|c|c|c|c|c|}
\hline \multirow{2}{*}{ Sorbent } & \multicolumn{3}{|c|}{$\begin{array}{c}\text { Freundlich isotherm } \\
\text { constants }\end{array}$} & \multicolumn{4}{|c|}{ Lanqmuir isotherm constants } \\
\hline & $\mathrm{n}$ & $\mathrm{K}_{\mathrm{F}}$ & $\mathrm{R}^{2}$ & $\begin{array}{l}\mathrm{K}_{\mathrm{L}}, \\
l / g\end{array}$ & $\begin{array}{l}a_{\mathrm{L}} \\
l / m g\end{array}$ & $\mathrm{R}_{\mathrm{L}}$ & $\begin{array}{l}\mathrm{Q}_{\max }, \\
m q / g\end{array}$ \\
\hline $\begin{array}{c}\text { Carboxylate } \\
\text { containing copolymer }\end{array}$ & 1.0026 & 12.31 & 0.989 & 13.61 & 0.0259 & 0.047 & 483.1 \\
\hline
\end{tabular}

The data of Table 4 shows that the sorption process can be considered as profitable $(\mathrm{RL}=0,047)$; maximum value of SCS $(483.1 \mathrm{mg} / \mathrm{g})=\mathrm{C}_{0}$ is reached at 778.8 $\mathrm{mg} / \mathrm{l}$.

To find the possibility of reusing the copolymer, the experiments on its regeneration through the use of hydrochloric acid of various concentrations were carried out. The process proceeded at room temperature under static conditions for 24 hours. The results of these experiments are presented in Table 5.

Table 5. Results of desorption of $\mathrm{UO}_{2}{ }^{2+}$-ions with hydrochloric acid ( $\left.\mathrm{HCl}\right)$

\begin{tabular}{|c|c|c|c|}
\hline $\begin{array}{c}\text { Acid } \\
\text { concentration, } M\end{array}$ & $\begin{array}{c}\text { Activity of isotope } \\
{ }^{235} \mathrm{U} \text { in aqueous } \\
\text { solution, Bk/l }\end{array}$ & $\begin{array}{c}\text { Concentration } \mathrm{UO}_{2}{ }^{2+} \text {-ions } \\
\text { in aqueous solution (after } \\
\text { desorption), mg/l }\end{array}$ & $\begin{array}{c}\text { Degree of } \\
\text { sorption, \% }\end{array}$ \\
\hline 0 & 1.25 & 2.46 & 1.2 \\
\hline 0.00051 & 10.9 & 21.4 & 9.2 \\
\hline 0.00075 & 19.5 & 38.35 & 16.5 \\
\hline 0.003 & 28.5 & 56.25 & 24.2 \\
\hline 0.005 & 39.5 & 77.68 & 33.5 \\
\hline 0.001 & 56.7 & 111.41 & 48.0 \\
\hline 0.05 & 75.4 & 148.29 & 63.9 \\
\hline 0.1 & 85.6 & 168.35 & 72.5 \\
\hline 0.3 & 102.9 & 202.37 & 87.2 \\
\hline 0.75 & 110.2 & 216.73 & 93.4 \\
\hline 1.5 & 114.4 & 225.0 & 96.9 \\
\hline 2.0 & 112.4 & 221.05 & 95.3 \\
\hline
\end{tabular}

As is seen from Table, when using diluted solutions of hydrochloric acid, a degree of desorption of $\mathrm{UO}_{2}{ }^{2+}$-ions doesn't exceed $24,2 \%$.

When using an acid in the concentration (from 0.1 to $0.3 \mathrm{M}$ ), a degree of desorption of uranyl-ions is 72.5 and $87.2 \%$, respectively. A maximum degree of desorption of $\mathrm{UO}_{2}{ }^{2+}$-ions ( $~ 97 \%)$ is attained when using an acid of $1 \mathrm{M}$ concentration. 


\title{
CONCLUSION
}

Thus, the results of the analysis make it possible to recommend the cross-linked copolymer obtained by radical copolymerization of styrene, maleic anhydride and new cross-linking comonomer-1,3-bis(propenylphenoxy)-propane as sorbent for effective purification of aqueous solutions from uranium salts.

\section{REFERENCES}

1. Vlasova N.N., Oboronina Je.N., Grigorieva O.Ju., Voronkov M.G. Organosilicon Ion-Exchange and Complexing Adsorbents. Russian Chem.Rev. 2013, vol. 82, no.5, pp. 449-464.

2. Maharramov A.M., Bairamov M.R., Agayeva M.A. et al. Akenylphenols: preparation, transformation and applications. Russian Chemical Reviews. 2015, vol. 84, no. 11, pp. 1258-1278

3. Maharramov A.M., Bairamov M.R., Garibov A.A. et al. The analysis of nitro-containing cross-linked copolymers of maleic anhydride and styrene as chelating sorbents for extracting uranyl-ions from water systems. Journal of Environmental Analytical Chemistry. 2017, vol.4, issue 3, pp. 14. Doi:10.41722380-2391.1000205

4. Perlova O.V., Sazanova V.F., Perlova N.A. and Yaroshenko N.A. Kinetics of Sorption of Uranium(VI) Compounds with Zirconium-Silica Nanosorbents. Russian Journal of Physical Chemistry A. 2014, vol. 88, no. 6, pp. 1012-1019. DOI: $10.1134 /$ S0036024414060223.

5. Magerramov A.M., Bairamov M.R., Garibov A.A. Investigation of the terpolymer of maleic anhydride, styrene and 1,4-di (4-isopropenylphenoxy) butane as a sorbent for extraction of $\mathrm{UO}_{2}{ }^{2+}$ ions from aqueous systems. Zhurnal Prikladnoi Khimii The Russian Journal of Applied Chemistry. 2011, vol. 84, no. 1, pp. 151-155.

6. Magerramov A.M., Bairamov M.R., Allahverdieva M.G. Investigation of sulphocathionite based on styrene copolymer and 1,4-di (4isopropenylphenoxy) butane as a sorbent for the recovery of uranyl ions from aqueous solutions. Azerbaijan Technical University. Scientific proceedings. Fundamental sciences. 2010, vol. IX(35), no. 3, pp. 110-112.

\section{ОЧИСТКА ВОДЫ ОТ УРАНИЛ-ИОНОВ С ПОМОЩЬЮ НОВОГО СОРБЕНТА КАРБОКСИЛАТНОГО ТИПА}

\author{
${ }^{a}$ А.М. Магеррамов, ${ }^{a}$ Г.М. Аскарова, ${ }^{a}$ М.Р. Байрамов, ${ }^{b}$ Дюс.А. Нагиев, \\ ${ }^{a}$ М.А. Агаева, ${ }^{a}$ Ш.Джс. Гулиева, ${ }^{a}$ Г.М. Гасанова \\ Бакинский государственный университет \\ AZ 1148 Баку, ул. 3.Халилова, 23; e-mail: gull.askar@mail.ru \\ Национальный иенттр ядерных исследований \\ AZ 1073, Баку, пр. Иншаатчьлар, 4
}

Гидролизованный тройной сополимер стирола, малеинового ангидрида и 1,3-бис(пропенилфенокси)пропана исследован в качестве сорбента для извлечения уранил-ионов из водных систем. Изучено влияние рН среды, концентраџии уранил-ионов, количества сорбента, продолжительности сорбции и др. факторов на основные показатели 
процесса сорбции. С применением уравнений Ленгмюра и Фрейндлиха проведен анализ изотерм сорбиии уранил-ионов. Установлена возможность использования сополимера как в концентрированных, так и разбавленных растворах.

Ключевье слова: сшитые полимеры, изотермы собции, уранил-ионы, регенерация

\title{
SULU SISTEMLORIN URANIL-IONLARDAN YENİ KARBOKSILAT TIPLI SORBENT VASITTOSI ILO TOMIZLONMOSI
}

\author{
${ }^{a}$ A.M. Məhərromov, ${ }^{a}$ M.R. Bayramov, ${ }^{a}$ G.M. Osgarova,${ }^{b}$ C.A. Nă̆ıyev, \\ ${ }^{a}$ M.A. A Ăayeva, ${ }^{a}$ Ş.C. Quliyeva, ${ }^{a}$ G.M. Hosonova \\ ${ }^{a}$ Bakı Dövlat Universiteti \\ AZ 1148 Bakl,Z.Xəlilov küç., 23; e-mail: gull.askar@mail.ru \\ ${ }^{b}$ Milli Nüvə Tadqiqatları Markəzi \\ AZ 1073, Bakı, Inşaatçılat pr., 4
}

Sulu sistemlərindən uranil-ionlarının təmizlənməsi üçün hidroliz olunmuş stirol, malein anhidridi, 1,3-bis-(propenilfenoksi)propan asasında alınmış üçlü sopolimerindon sorbent kimi istifadə olunmuşdur. Sorbsiya prosesinin asas göstəricilarina mühitin $\mathrm{pH}$-i, uranil-ionlarının qatıliğl, sorbentin miqdarl, sorbsiya vaxtı vo s. faktorların təsiri öyranilmişdir. Lenqmür va Freyndlix tənliylarindən istifado edərək uranil-ionlarının sorbsiya izotermlarinin təhlili aparılmışdır. Sopolimerin qatı və duru məhlullarda istifadəsinin mümkünlüyü təsdiq edilmişdir. Açar sözlar: tikili polimer, sorbsiya, uranil-ionlarl, sorbsiya izotermlari, regenerasiya 